\title{
Epidemiological characterization and risk factors associated with lentiviral infection of small ruminants at animal fairs in the semiarid Sertão region of Pernambuco, Brazilian semiarid
}

\section{Caracterização epidemiológica e fatores de risco associados às lentiviroses em pequenos ruminantes comercializados em feira de animais no Sertão de Pernambuco, semiárido brasileiro}

\author{
José Romero Alexandre Alves ${ }^{1}$; Clécio Henrique Limeira²; \\ Geilson Manoel de Souza Lima ${ }^{3}$; Raymundo Rizaldo Pinheiro"; \\ Francisco Selmo Fernandes Alves ${ }^{4}$; Vanderlan Warlington Souza dos Santos ${ }^{5}$; \\ Sérgio Santos de Azevedo ${ }^{6}$; Clebert José Alves ${ }^{6^{*}}$
}

\begin{abstract}
Animal agglomerations at commercial events such as trade fairs represent an important facilitator in infectious disease transmission. Thus, it is crucial to understand the epidemiology of infectious diseases in small ruminants. The objective of this study was to examine lentiviral presence in goats and sheep traded at the animal fair of Tabira city (Sertão region of Pernambuco) and identify possible risk factors associated with infection. We collected serum samples from 233 crossbred goats and 119 crossbred sheep, belonging to 12 breeders, at the Tabira livestock fair from November 2014 to June 2015. An epidemiological questionnaire was used to analyze the risk factors. Agar gel immunodiffusion (AGID) and western blotting (WB) were performed to diagnose small ruminant lentivirus (SRLV) infection. In the AGID test, we used maedi-visna virus (MVV) antigens for sheep and caprine arthritis/encephalitis virus (strain Cork) (CAEVCo) antigen for goats. The WB analysis used CAEV-Co antigen for both species. Variables from the questionnaire were analyzed with univariate and multivariate statistics. One seropositive goat but no sheep was identified via AGID. According to the WB results, $15 / 233$ goats $(6.44 \%$; CI95\% $=3.94-10.35 \%)$ and $8 / 119$ sheep $(6.72 \%$; CI95\% $=3.45-12.71 \%)$ were seropositive, totaling $23 / 352$ reactive animals $(6.53 \%$; CI $95 \%=4.39-9.61 \%)$ from 12 herds. Annual vermifugation of the animals was a significant risk factor (odds ratio $=5.9 ; \mathrm{CI} 95 \%=1.7-19.8 ; \mathrm{p}=0.04$ ) for disease in goats, but no variables associated with infection risks were identified in sheep. We concluded that SRLV was present in goats and sheep at the animal fair. Western blots were more sensitive than AGID for SRLV diagnosis. Practices aiming to improve sanitary management may reduce the risk of infection in goats. All studied herds included animals identified as seropositive for SRLV. Therefore, we recommend adopting measures that increase disease diagnosis while intensifying traffic control and surveillance of animal agglomerations.

Key words: Agar gel immunodiffusion. Agglomerations. Lentivirus. Small Ruminants. Western Blotting.
\end{abstract}

\footnotetext{
${ }^{1}$ Discentes, Curso de Doutorado, Programa de Pós-Graduação em Medicina Veterinária, Universidade Federal de Campina Grande, UFCG, Patos, PB, Brasil. E-mail: j.romeroalves@bol.com.br

2 Discente, Curso de Mestrado, Programa de Pós-Graduação em Medicina Veterinária, UFCG, Patos, PB, Brasil. E-mail: cleciolimeira@hotmail.com

3 Discente, Curso de Graduação em Medicina Veterinária, UFCG, Patos, PB, Brasil. E-mail: geilsonmsl@hotmail.com

${ }^{4}$ Pesquisadores, Empresa Brasileira de Pesquisa Agropecuária, EMBRAPA Caprinos e Ovinos, CNPC, Sobral, CE, Brasil. E-mail: rizaldo.pinheiro@embrapa.br; selmo.alves@embrapa.br

5 Discente, Curso de Doutorado, Programa de Pós-Graduação em Ciência Animal, Universidade Federal Rural do Semiárido, UFERSA, Mossoró, RN, Brasil. E-mail: vanderlansouza@gmail.com

${ }^{6}$ Profs. Drs., Programa de Pós-Graduação em Medicina Veterinária, UFCG, Patos, PB, Brasil. E-mail: sergio.azevedo@pq.cnpq. br; clebertja@uol.com.br

* Author for correspondence
} 


\section{Resumo}

Aglomerações de animais em eventos comerciais do tipo feiras de negócios representam um importante elo na transmissão de doenças infecciosas, resultando na importância do conhecimento acerca da epidemiologia das doenças de pequenos ruminantes. Desta forma, o objetivo desse estudo foi determinar a presença das lentiviroses em caprinos e ovinos comercializados na feira de animais da cidade de Tabira, Sertão de Pernambuco, bem como a identificação de possíveis fatores de risco associados à enfermidade. Foram coletadas amostras de soro de 233 caprinos e 119 ovinos, sem raça definida, pertencentes a doze proprietários, na feira de animais vivos do município no período de novembro de 2014 a junho de 2015. Foi aplicado questionário epidemiológico para análise dos fatores de risco. O diagnóstico da infecção por Lentivirus de Pequenos Ruminantes (LVPR) nas espécies foi realizado pela Imunodifusão em ágar-gel (IDGA) e Western Blotting (WB). Na IDGA foram utilizados antígenos de Vírus Maedivisna (MVV) para ovinos e de vírus da Artrite-Encefalite Caprina (CAEV), cepa CAEV- Cork para caprinos, e no WB foi utilizado a cepa CAEV- Cork como antígeno para ambas espécies. As variáveis obtidas no questionário foram submetidas a análises estatísticas univariada e multivariada. Pela técnica de IDGA foi possível identificar um caprino soropositivo. Não foi detectada positividade nos ovinos. No WB 15/233 (6,44\%; IC95\% = 3,94 - 10,35\%) caprinos e 8/119 $(6,72 \%$; IC95\% $=3,45-12,71 \%)$ ovinos foram soropositivos, totalizando 23/352 (6,53\%; IC95\% = 4,39-9,61\%) animais reagentes. Os doze rebanhos estudados apresentaram animais soropositivos. Vermifugar os animais anualmente (odds ratio $=5,9 ;$ IC $95 \%=1,7-19,8 ; p=0,04)$ foi identificado como fator de risco para enfermidade em caprinos. Não foram identificadas variáveis associadas ao risco de infecção em ovinos. Concluiu-se que os LVPR estão presentes em caprinos e ovinos comercializados na feira de animais. A técnica de WB apresentou maior sensibilidade que a IDGA para diagnóstico dos LVPR. Melhorias nas práticas de manejo sanitário podem reduzir o risco de infecção nos caprinos. Todos os rebanhos estudados apresentaram animais soropositivos para lentiviroses de pequenos ruminantes (SRLV), sendo recomendado adotar medidas que possibilitem aumentar o diagnóstico da doença e intensificar o controle de trânsito e fiscalização das aglomerações animais.

Palavras-chave: Aglomerações. Imunodifusão em ágar-gel. Lentivirus. Pequenos Ruminantes. Western Blotting.

\section{Introduction}

Goat and sheep breeding in northeastern Brazil continues to face structural and sanitation problems that lower economic feasibility, despite considerable effort to address this issue (SOUSA, 2007). As a consequence, most farmers breed small ruminants as a secondary activity and frequently sell the animals at livestock fairs to profit from this production (COELHO et al., 2011).

Goat and sheep commercialization at livestock fairs can occur through the farmers directly or through intermediary traders who resell animals purchased from farms (NOGUEIRA FILHO et al., 2010). The animal fair of the Tabira - PE municipality has performed large-scale sales of cattle, small ruminants, pigs, and horses for over 50 years. This fair integrates the region's cattle production and is the second largest animal market in the State of Pernambuco (NUNES, 2013). Such events occur frequently across Northeast Brazil, contributing to regional economic development and growth (MAIA, 2007). However, the agglomeration of animals at these fairs facilitates contact between susceptible individuals and sources of infectious disease, representing a risk for transmission and dissemination.

To improve and consolidate measure on animal health production, the National Sheep and Goat Health Program (PNSCO) in Brazil requires information on the status of diseases affecting small ruminants (SANTIAGO et al., 2012). Among these are diseases linked to lentiviruses, which cause significant economic losses in goat and sheep production (CALLADO et al., 2001). In Brazil, the average prevalence of caprine arthritis encephalitis (CAEV) and the maedi-visna virus (MVV) are 
$10.7 \%$ and $4.6 \%$, respectively (PINHEIRO et al., 2012). Previous serologic studies reported that both diseases are widespread throughout the northeast, ranging from $0.29 \%$ prevalence in Bahia (LIMA et al., 2013) to $11.0 \%$ in Rio Grande do Norte (SILVA et al., 2005) for CAEV, and from $0.11 \%$ in Sergipe (MENDONÇA et al, 2013) to 31.67\% in Ceará (ALMEIDA et al., 2003) for MVV. These results reinforce the need for seroepidemiological studies in the region that elucidate the transmission mechanisms of lentiviral diseases.

This study was performed to address the importance of animal agglomerations in disease transmission and dissemination, as well as the need to generate SRLV epidemiology- and diagnosisrelated information that strengthens PNSCO's work. Our objective was to determine the presence of anti-SRLV antibodies in goats and sheep that were marketed at the Tabira animal fair, in northeastern Brazil. We also aimed to identify risk factors associated with infection in small ruminants.

\section{Material and Methods}

\section{Characterization of the study area}

The study was conducted at the livestock fair of Tabira city $\left(07^{\circ} 35^{\prime} 31^{\prime \prime} \mathrm{S}, 37^{\circ} 32^{\prime} 24^{\prime \prime} \mathrm{W}\right)$, located in the Sertão Development Region of Pernambuco, in the northeastern semiarid region of Brazil. The fair takes place weekly, from Tuesday to Wednesday afternoon, and includes animals from Pernambuco and other northeastern states. The fair is mainly held for cattle and small-ruminant trade, but swine and poultry trade also occurs.

\section{Study design}

The study population comprised sheared goat and sheep adults (age: $>6$ months) of both sexes, with no defined breed. To calculate the sample number, we considered the following parameters: (a) $50 \%$ expected prevalence (used to maximize the sample); (b) $6 \%$ absolute error; (c) 95\% confidence level (CI) based on the formula for simple random samples. We were able to include 352 samples, well above the minimum sample ("n") of 266 animals according to the listed parameters. Owners were selected to participate in the research through a convenience sample (THRUSFIELD, 2007). The per-collection sample number was based on the total number of animals that entered the fair. These data were obtained through the fair's animal entry report and the Animal Transit Guides (ATGs) presented by the breeders at the entrance to the fair. Additional data were provided by the Agency for Defense and Agricultural Inspection of the State of Pernambuco (ADAGRO). Twelve owners agreed to participate in our research and signed the Terms of Free and Informed Consent. Animals were randomly selected from those present in the facilities where trading was performed. The same farmer was not repeatedly sampled, even if the farmer owned multiple. Serum samples were collected from all adults in each herd belonging to every participating owner. Table 1 presents data on collection date distribution, number of sampled goats/sheep per property, and municipality of origin.

\section{Sample collection}

Blood samples were collected monthly from 233 goats and 119 sheep $(\mathrm{n}=352)$ during November 2014 to June 2015. These were collected in sterile 8-mL vacuum tubes, labeled and conditioned in isothermal boxes under refrigeration, then taken to the Laboratory of Transmittable Diseases of the Health and Rural Technology Center of the Federal University of Campina Grande. Samples were centrifuged, and the serum samples were stored at $-20^{\circ} \mathrm{C}$ until needed for serological tests. Of the included goats, 206 were from Pernambuco and 27 from Bahia, while 93 sheep were from Pernambuco and 26 were from Bahia. 
Table 1. Sample distribution per owner, county of origin, and number of animals sampled by herd between November 2014 and June 2015, at an animal fair in the municipality of Tabira-PE, semiarid region of Brazil.

\begin{tabular}{ccccccc}
\hline Date of collection & Owner & Municipality/UF (origin) & UF & Goats & Sheep & Animal total \\
\hline $04 / 11 / 2014$ & A & Casa Nova & Bahia & 25 & & 25 \\
$04 / 11 / 2014$ & B & Tabira & Pernambuco & & 25 & 25 \\
$09 / 12 / 2014$ & C & Remanso & Bahia & 2 & 28 & 30 \\
$09 / 12 / 2014$ & D & Solidão & Pernambuco & & 22 & 22 \\
$09 / 12 / 2014$ & E & Tabira & Pernambuco & & 20 & 20 \\
$14 / 01 / 2015$ & F & Tabira & Pernambuco & 61 & 7 & 68 \\
$24 / 03 / 2015$ & G & Calumbi & Pernambuco & 2 & 4 & 6 \\
$24 / 03 / 2015$ & H & Tabira & Pernambuco & 2 & 9 & 11 \\
$24 / 03 / 2015$ & I & Sertânia & Pernambuco & 6 & 4 & 10 \\
$21 / 04 / 2015$ & J & São José do Egito & Pernambuco & 55 & & 55 \\
$18 / 05 / 2015$ & L & Brejinho & Pernambuco & 30 & & 30 \\
$16 / 06 / 2015$ & M & Santa Terezinha & Pernambuco & 50 & & 50 \\
\hline Total & 12 & 9 & & 233 & 119 & 352 \\
\hline
\end{tabular}

Diagnosis of SRLV infection

Serological tests for detecting anti-SRLV antibodies were performed at the National Goat and Sheep Research Center of the Brazilian Agricultural Research Corporation (Embrapa Caprinos e Ovinos - CNPC, Sobral - CE). Agar gel immunodiffusion (AGID) and western blots (WB) were used to detect infection.

Methods for AGID followed Pinheiro (2001). Antigens of the MVV strains (for sheep serum samples) and of CAEV (Cork strain, CAEV-Co; for goat serum samples) were produced through ultrafiltration in an AMICON® system. To visualize the precipitation lines, a reading was performed after 48 and 72 hours, with indirect light on a dark background; the second reading was considered definitive.

Methods for WB followed Pinheiro et al. (2011). Antigen for CAEV-Co was produced via ultracentrifugation in a sucrose gradient. Samples showing bands close to $28 \mathrm{kDa}$ were deemed positive, as this molecular weight corresponds to the viral capsid protein.

\section{Statistical analysis}

Diagnostic test results and answers from the epidemiological questionnaire given to each owner were entered into Microsoft Excel®. Risk variables associated with animal seropositivity were calculated using univariate and multivariate analyses. A univariate chi-square test (ZAR, 1999) was first used to analyze the association of each independent variable with the dependent variable. Significant variables $(p \leq 0.2)$ were then subjected to multiple logistic regression (HOSMER; LEMESHOW, 2000). The significance level for the latter analysis was 5\%. All statistics were performed in SPSS 20.0 for Windows ${ }^{\circledR}$.

\section{Ethical procedures}

The project was approved by the Research Ethics Committee (REC) of the Center for Health and Rural Technology - CSTR/UFCG, and filed under the number $184 / 2014$. 


\section{Results}

According to the AGID analysis, $0.42 \%$ of the goats $(1 / 233)$ were seropositive, whereas all sheep were negative. The WB results revealed that $15 / 233$ goats $(6.44 \%, 95 \% \mathrm{CI}=3.94-10.35 \%)$ and $8 / 119$ sheep $(6.72 \%, 95 \%$ CI $=3.45-12.71 \%)$ were seropositive, totaling 23/352 seropositive animals $(6.53 \%, 95 \%$ CI $=4.39-9.61 \%)$ (Table 2$)$.
Sampled goat herds belonged to farmers from the Brejinho, Calumbi, Santa Terezinha, São José do Egito, Sertânia, and Tabira municipalities from Pernambuco, as well as the Casa Nova and Remanso municipalities from Bahia (Table 3). Sheep herds belonged to farmers from the municipalities of Calumbi, Sertânia, and Solidão from Pernambuco, as well as Remanso from Bahia (Table 4).

Table 2. Total number of seropositive (for SRLV) animals from total tested goats and sheep, based on agar gel immunodiffusion (AGID) and western blot (WB) results, at an animal fair in the municipality of Tabira-PE, Brazil. Samples were collected between November 2014 and June 2015.

\begin{tabular}{lcccc}
\hline & \multicolumn{2}{c}{ AGID } & \multicolumn{2}{c}{ Western blotting } \\
\cline { 2 - 5 } Species & Total tested & Positive (\%) & Total tested & Positive (\%) \\
\hline Goats & 233 & $1(0.43)$ & 233 & $15(6.44)$ \\
Sheep & 119 & $0(0.00)$ & 119 & $8(6.72)$ \\
\hline Total & $\mathbf{3 5 2}$ & $\mathbf{1 ( 0 . 2 8 )}$ & $\mathbf{3 5 2}$ & $\mathbf{2 3 ( 4 . 3 2 )}$ \\
\hline
\end{tabular}

Table 3. Municipality of origin, total number of tested herds, as well as number of tested and SRLV-seropositive goats (based on WB results), at a fair in Tabira-PE, Brazil. Samples were taken between November 2014 and June 2015.

\begin{tabular}{lcccc}
\hline Municipality & UF & Tested herds & Tested animals & Total positive \\
\hline Brejinho & Pernambuco & 1 & 30 & 1 \\
Calumbi & Pernambuco & 1 & 4 & 1 \\
Casa Nova & Bahia & 1 & 25 & 4 \\
Remanso & Bahia & 1 & 2 & 1 \\
Santa Terezinha & Pernambuco & 1 & 50 & 1 \\
São José do Egito & Pernambuco & 1 & 55 & 2 \\
Sertânia & Pernambuco & 1 & 4 & 1 \\
Tabira & Pernambuco & 2 & 63 & 4 \\
\hline Total & & $\mathbf{9}$ & $\mathbf{2 3 3}$ & $\mathbf{1 5}$ \\
\hline
\end{tabular}

Table 4. Municipality of origin, total number of tested herds, as well as number of tested and SRLV-seropositive sheep (based on WB), at fairs occurring during Novemeber 2014 and June 2015, in Tabira-PE, Brazil.

\begin{tabular}{lcccc}
\hline Municipality & UF & Tested herds & Tested animals & Total positive \\
\hline Calumbi & Pernambuco & 1 & 2 & 0 \\
Remanso & Bahia & 1 & 28 & 1 \\
Sertânia & Pernambuco & 1 & 6 & 0 \\
Solidão & Pernambuco & 1 & 22 & 2 \\
Tabira & Pernambuco & 4 & 61 & 5 \\
\hline Total & & $\mathbf{8}$ & $\mathbf{1 1 9}$ & $\mathbf{8}$ \\
\hline
\end{tabular}


Ten out of 132 males (7.57\%) were seropositive, of which 06/73 (8.21\%) were goats and 04/59 $(6.78 \%)$ were sheep. Thirteen out of 220 females (5.90\%) were seropositive, of which 09/160 (5.62\%) were of goats and $04 / 60(6.66 \%)$ were sheep.

All tested herds had at least one seropositive animal (goat and/or sheep). During the study period, the fair included 16434 goats and 25759 sheep. For goats, 6972 Animal Transit Guides (ATGs) were recorded: 2804 for animal entry and 4168 were for animal exit. For sheep, 3634 entry ATGs and 5324 exit ATGs were issued, totaling 8958 ATGs.

Table 5 lists the variables associated with SRLV positivity in goats $(\mathrm{p} \leq 0.2$; chi-square test). The logistic regression (Table 6) identified annual vermifugation of the animals as a risk factor for lentiviruses in goats (odds ratio $=5.9$ ). However, no variables were associated with lentivirus positivity among sheep $(\mathrm{p} \leq 0.2)$.

Table 5. Chi-sqare results, showing variables most highly associated $(p<0.2)$ with seropositivity for lentivirus in goats marketed at animal fairs in Tabira-PE, Brazil, between November 2014 and June 2015.

\begin{tabular}{|c|c|c|c|c|}
\hline Variable & Category & Animal total & No. of positive animals (\%) & p \\
\hline \multirow[t]{3}{*}{ Activity } & Rural Prod. & 147 & $7(4.8)$ & \\
\hline & Employee & 61 & $4(6.6)$ & \\
\hline & Merchant & 25 & $4(16.0)$ & 0.106 \\
\hline \multirow[t]{3}{*}{ Profile } & Owner & 150 & $8(5.3)$ & \\
\hline & Half owner/renter & 56 & $2(3.6)$ & \\
\hline & Others & 27 & $5(18.5)$ & 0.022 \\
\hline \multirow[t]{2}{*}{ Breeds sheep } & No & 105 & $3(2.9)$ & \\
\hline & Yes & 128 & $12(9.4)$ & 0.044 \\
\hline \multirow[t]{3}{*}{ Breeding type } & Non-intensive & 54 & $2(3.7)$ & \\
\hline & Semi-intensive & 154 & $9(5.8)$ & \\
\hline & Intensive & 25 & $4(16.0)$ & 0.103 \\
\hline \multirow[t]{2}{*}{ Exploitation } & Meat & 50 & $1(2.0)$ & \\
\hline & Mixed & 183 & $14(7.7)$ & 0.128 \\
\hline \multirow[t]{2}{*}{ Facilities } & Ground beaten barn & 231 & $14(6.1)$ & \\
\hline & Paved barn & 2 & $1(50.0)$ & 0.012 \\
\hline \multirow[t]{3}{*}{ Goat herd } & From 01 to 50 & 30 & $1(3.3)$ & \\
\hline & From 50 to 100 & 170 & $8(4.7)$ & \\
\hline & More than 100 & 33 & $6(18.2)$ & 0.012 \\
\hline \multirow[t]{3}{*}{ Sheep herd } & From 01 to 50 & 116 & $9(7.8)$ & \\
\hline & From 50 to 100 & 4 & $1(25)$ & \\
\hline & More than 100 & 8 & $2(25)$ & 0.149 \\
\hline \multirow[t]{2}{*}{ Uses caatinga as food } & No & 27 & $4(14.8)$ & \\
\hline & Yes & 206 & $11(5.3)$ & 0.08 \\
\hline \multirow[t]{2}{*}{ Notes on sanitary management } & No & 198 & $9(4.5)$ & \\
\hline & Yes & 35 & $6(17.1)$ & 0.014 \\
\hline \multirow[t]{2}{*}{ Vaccination against rabies } & No & 88 & $9(10.2)$ & \\
\hline & Yes & 145 & $6(4.1)$ & 0.066 \\
\hline \multirow[t]{3}{*}{ Vermifugation frequency } & Quaterly or less & 141 & $6(4.3)$ & \\
\hline & Semiannually & 63 & $3(4.8)$ & \\
\hline & Annual & 29 & $6(20.7)$ & 0.04 \\
\hline \multirow[t]{2}{*}{ Requests a veterinarian } & No & 92 & $9(9.8)$ & \\
\hline & Yes & 141 & $6(4.3)$ & 0.081 \\
\hline
\end{tabular}


Table 6. Significant risk factor for lentivirus infection in goats marketed at animal fairs in Tabira - PE, Brazil, occurring between November 2014 and June 2015.

\begin{tabular}{lccc}
\hline Risk factor & Odds ratio (OR) & CI 95\% & $p$ \\
\hline Annual vermifugation of the herd & 5.9 & $1.7-19.8$ & 0.04 \\
\hline
\end{tabular}

\section{Discussion}

The study's results showed that WB was more sensitive than AGID in detecting anti-SRLV antibodies, in agreement with a study in Bahia by Sardi et al. (2012). The authors showed that AGID was unable to detect seropositive animals, while the ELISA-indirect method detected $0.66 \%$ of seropositive goats, a result that confirmed with WB. Due to its low cost, practicality, and general specificity, AGID is recommended by the World Organization for Animal Health (OIE, 2008). However, its sensitivity to anti-SRLV antibodies appears moderate, underestimating the actual infection level in screened herds (OLIVEIRA et al., 2008). Western blotting is a more sensitive test that can detect antibodies at a dilution up to 128 times higher than AGID; thus, it is the method of choice for detecting antibody levels in herds (PINHEIRO et al., 2012).

The frequency of seropositive goats $(6.44 \%)$ in this study corroborates other reports from the northeast region that used AGID as a diagnostic. For example, Teixeira et al. (2016a) found 2.8\% seropositivity in Maranhão, while Batista et al. (2004) detected 2.5\% seropositivity in Piauí. In Ceará and Rio Grande do Norte, 1\% (PINHEIRO et al., 2001) and 11\% (SILVA et al., 2005) seropositivity were observed, respectively. Several other studies in Paraíba reported 8.2\%, 2.2\%, and $8.1 \%$ seropositivity (CASTRO et al., 2002; BANDEIRA et al., 2008; SILVA et al., 2013). Data from Pernambuco indicate 3.8\% (OLIVEIRA et al., 2006) and 1.89\% (MELO et al., 2016) seropositivity. Finally, Lima et al. (2013) identified $0.29 \%$ seropositive goats in Bahia.

We detected $6.53 \%$ seropositive sheep, slightly higher than data from in other sheep serological studies in Northeast Brazil. For example, 0.11\% and $0.34 \%$ of tested sheep were seropositive studies from Sergipe (MENDONÇA et al., 2013) and Bahia (MARTINEZ et al., 2009), respectively. Data from Pernambuco revealed $5.2 \%, 1.07 \%$ and $0.26 \%$ seropositivity (OLIVEIRA et al., 2006; COSTA et al., 2007; MELO et al., 2016). In Maranhão and Ceará, seropositivity prevalence was $0.7 \%$ (TEIXEIRA et al., 2016b) and 31.67\%, respectively (ALMEIDA et al., 2003). The fact that the latter study sampled sheep showing clinical signs of pneumonia likely explains the considerably higher seropositivity, as the other reports focused on herds lacking animals exhibiting symptoms compatible with MVV. Despite the low frequency observed in most of the studies, the data clearly show that the disease is widespread in northeastern Brazilian states, suggesting the need to stop dissemination through better control measures.

Most subject animals were categorized as No Defined Breeding Pattern (NDBP), which probably contributed to the observed low frequency. Pinheiro et al. (2001) investigated anti-SRLV antibodies in goats from Ceará, observing seropositivity in $0.13 \%$ of the crossbred animals (Brown Highland $\times$ NDBP, Saanen $\times$ NDBP) and in $5.02 \%$ of the purebred animals (Brown Highland, Saanen, and Anglo Nubian). Additionally, a significant difference in seropositivity between NDBP (3.0\%), half-blood (31\%; NDBP vs. purebred), and purebred (66\%; Saanen, Alparda, Anglo Nubian and Toggenburg) dairy goats from Ceará was also observed. These results confirm that NDBP animals are less susceptible to infection than a defined breed, typically bred in more intensive management systems that can contribute to disease transmission. 
In this study, seropositivity was $3.7 \%$ for goats in non-intensive breeding programs, $5.8 \%$ for those under semi-intensive breeding, and $16 \%$ for those bred in intensively. In sheep, the frequency of seropositive animals was $8.0 \%, 8.1 \%$, and $5.3 \%$ in intensive, semi-intensive, and non-intensive breeding systems, respectively. This result can be attributed to how breeding systems influence viral dissemination in a herd, with transmission risks increasing as contact among animals increases (MOURA SOBRINHO et al., 2010). Intensive breeding has been reported by live-animal traders, who keep purchased animals confined in small facilities until they are traded at fairs.

Most interviewed owners stated that they did not adopt efficient sanitation measures, failing to perform practices such as zootechnical control, quarantine of newly acquired animals, isolation of sick animals, control of entry/exit from the herd, and frequent cleaning of the facilities. In facilities that were cleaned weekly or biweekly, seropositive animals were not present in herds, whereas facilities that were never cleaned or cleaned only monthly exhibited $3.2 \%$ and $12.7 \%$ seropositive animals, respectively.

Annual herd vermifugation was found to be a risk factor for goat infection. This result suggests that vermifugation efforts by owners may be insufficient, because the recommended schedule for this practice is to do so during both the rainy and dry seasons (RIET-CORREA et al., 2013). SRLV weakens animals, favoring the development of other diseases and possibly an increase in the gastrointestinal parasitic load of small ruminants. Indeed, goats with intense gastrointestinal verminosis experience immunosuppression (SILVA et al., 2002). Therefore, CAEV-infected goats may be predisposed to a greater parasitic load due to their weakened immune system. We suggest that the relationship between SRLV and gastrointestinal parasitism causes a decline in immunity, making animals more susceptible to infection.
Ineffective vermifugation may also be related to the absence of adequate sanitary management. Specifically, the lack of proper sanitation contributes to SRLV survival in the herd (PINHEIRO et al., 2000). Improvements to general health management practices are thus warranted to minimize the risk of disease occurrence in goats.

No significant difference was observed between frequency and total number of seropositive males and females in either species. These results are in contrast with those of an epidemiological survey for CAE in Ceará, which found that males were more affected (PINHEIRO et al., 2001). Bandeira et al. (2008) reported a higher frequency of seropositive breeders $(28.3 \%)$ for goat lentivirus in $7.2 \%$ young female and $5.3 \%$ adult females in the Cariri region of Paraiba. This result indicates that males may be important sources of lentivirus infection in herds of the northeastern semiarid region.

In this study, western blots using the CAEV-Co strain as an antigen detected seropositive sheep, indicating a possible transmission of goat lentivirus to sheep. However, this hypothesis can only be confirmed with phylogenetic studies aimed at detecting viral strains that commonly infect different species in a breeding environment. Previous studies have suggested that cross-infection is associated with mixed breeding of goats and sheep (GJERSET et al., 2009; GREGO et al., 2007; PISONI et al., 2005), due to the close interspecific contact (PETERHANS et al., 2004). The goat lentivirus can be transmitted to sheep through direct contact with infected goats and through ingestion of their colostrum or milk (SOUZA et al., 2015). In seven of the eight sheep herds studied, mixed breeding of sheep and goats occurred, possibly facilitating viral transmission. Although no risk factors for infection were found in sheep, their disease occurrence was clearly influenced by contact with goats.

It should be noted that all herds sampled had at least one seropositive animal (goat and/or sheep). Despite the fact that herds from Calumbi-PE and 
Sertânia-PE did not contain seropositive sheep, seropositive goats were originally from herds with mixed breeding. This result indicates that SRLVs are widely distributed in goat and sheep herds marketed at the animal fair, representing a risk of transmission to susceptible individuals that come in contact with infection sources during agglomeration. Target herds are also at risk, as the fair includes animals that are sold to buyers from Pernambuco and neighboring states for breeding or fattening.

Agglomerations are very favorable to lentivirus dissemination, possibly due to the closely packed conditions and increased contact between susceptible animals (BROUGHTON-NEISWANGER et al., 2010; VILLORIA et al., 2013). Previous studies have demonstrated the importance of animal traffic as a risk factor for disease transmission and dissemination (BIGRAS-POULIN et al., 2007; CAPANEMA et al., 2012; DAVIES, 2002), which raises the possibility of viruses spreading to susceptible animals when infected animals are handled. Thus, agglomeration at animal fairs and the transit of small ruminants may be considered important facilitators for SRLV dissemination in the region. In efforts aimed at these diseases, PNSCO uses traffic control and regulation of animal agglomerations as the main strategic tools for managing goat and sheep diseases (BRASIL, 2009). Such strategies aim to track infection sources in potential outbreaks, controlling them and mitigating their diffusion to other regions (CARVALHO et al., 2012).

\section{Conclusion}

This study detected SRLVs in goats and sheep traded at the Tabira - PE animal fair. In view of the commercialization occurring at these events, we recommend an increase ininfection diagnosis of herds from the semiarid region, intensification of traffic control, and surveillance of animal agglomerations. Western blotting was more sensitive than AGID in diagnosing SRLV, demonstrating the importance of choosing the most effective serological diagnostic test for this disease. Because annual vermifugation was identified as a risk factor for infection in goats, we recommend improving methods that control gastrointestinal verminosis and encouraging basic sanitary management practices, to minimize the risk of disease.

\section{Acknowledgments}

The authors would like to thank the Agency for Defense and Agricultural Inspection of Pernambuco (ADAGRO) for animal-flux data; the National Council for Scientific and Technological Development (CNPq), for granting the financial support necessary for the project's development; and the Embrapa Caprinos: CNPC Sobral-CE, for providing the space and materials required to perform serological tests.

\section{References}

ALMEIDA, N. C.; TEIXEIRA, M. F. S.; FERREIRA, R. C. S.; CALlADO, A. K. C.; FROTA, M. N. L.; MELO, A. C. M.; APRÍGIO, C. J. L. Detecção de ovinos soropositivos para maedi/visna destinados ao abate na região metropolitana de Fortaleza. Veterinária Notícias, Uberlândia, v. 9, n. 1, p. 59-63, 2003.

BANDEIRA, D. A.; CASTRO, R. S.; AZEVEDO, E. O.; MELO, L. S. S.; MELO, C. B. Seroprevalence of Caprine Arthritis-Encephalitis Virus in goats in the Cariri region, Paraiba state, Brazil. The Veterinary Journal, Londres, v. 180, n. 3, p. 399-401, 2008.

BATISTA, M. C. S.; CASTRO, R. S.; CARVALHO, F. A. A.; CRUZ, M. S. P.; SILVA, S. M. M. S.; REGO, E. W.; LOPES, J. B. Anticorpos anti-Lentivírus de pequenos ruminantes em caprinos integrantes de nove municípios piauienses. Revista Ciência Veterinária dos Trópicos, Recife, v. 7, n. 2-3, p. 75-81, 2004.

BIGRAS-POULIN, M.; BARFOD, K.; MORTENSEN, S.; MATTHIAS, G. Relationship of trade patterns of the Danish swine industry animal movements network to potential disease spread. Preventive Veterinary Medicine, Londres, v. 80, n. 2-3, p. 143-165, 2007. 
BRASIL. Ministério da Agricultura Pecuária e Abastecimento. Manual de legislação: programas nacionais de saúde animal no Brasil. Brasília: Binagri, 2009. $440 \mathrm{p}$.

BROUGHTON-NEISWANGER, L. E.; WHITE, S. N.; KNOWLES, D. P.; MOUSEL, M. R.; LEWIS, G. S.; HERNDON, D. R.; HERRMANN-HOESING, L. M. Non-maternal transmission is the major mode of ovine lentivírus transmission in a ewe flock: A molecular epidemiology study. Infection, Genetics and Evolution, Montpellier, v. 10, n. 7, p. 998-1007, 2010.

CALLADO, A. K. C.; CASTRO, R. S.; TEIXEIRA, M. F. S. Lentivirus em pequenos ruminantes (CAEV e MaediVisna): revisão e perspectivas. Pesquisa Veterinária Brasileira, Seropédica, v. 21, n. 3, p. 87-97, 2001.

CAPANEMA, R. O.; HADDAD, J. P. A.; FELIPE, P. L. S. Trânsito de bovinos nos estados do Mato Grosso e Mato Grosso do Sul, Brasil. Arquivo Brasileiro de Medicina Veterinária e Zootecnia, Belo Horizonte, v. 64, n. 2, p. 253-262, 2012.

CARVALHO, L. F. R.; MELO, C. B.; HADDAD, J. P. A. Cadastro da exploração pecuária e o controle do trânsito de bovídeos considerando a saúde animal no Brasil. Uma breve revisão. Revista Brasileira de Medicina Veterinária, Rio de Janeiro, v. 34, n. 1, p. 19-26, 2012.

CASTRO, R. S.; AZEVEDO, E. O.; TABOSA, I.; NASCIMENTO, S. A.; OLIVEIRA, M. M. M. Anticorpos para o vírus da artrite-encefalite caprina em animais sem raça definida (SRD) de abatedouros dos estados de Pernambuco e Paraíba. Revista Ciência Veterinária nos Trópicos, Recife, v. 5, n. 2-3, p. 121- 123, 2002.

COELHO, M. C. S. C.; SOUZA, V. C.; COELHO, M. I. S.; CUNHA, M. P.; MEDINA, F. T. Aspectos sanitários de rebanhos caprinos e ovinos criados em assentamentos no município de Petrolina-PE. Revista Semiárido De Visu, Petrolina, v. 1, n. 1, p. 32-40, 2011.

COSTA, L. S. P.; LIMA, P. P.; CALLADO, A. K. C.; NASCIMENTO, S. A.; CASTRO, R. S. Lentivírus de pequenos ruminantes em ovinos Santa Inês: isolamento, identificação pela PCR e inquérito sorológico no estado de Pernambuco. Arquivos do Instituto Biológico, São Paulo, v. 74, n. 1, p. 11-16, 2007.

DAVIES, G. The foot and mouth disease (FMD) epidemic in the United Kingdom. Comparative Immunology, Microbiology and Infectious Diseases, Londres, v. 25, n. 2-3, p. 331-343, 2002.

GJERSET, B.; RIMSTAD, E.; TEIGE, J.; SOETAERT, K.; JONASSEN, C. M. Impact of natural sheep-goat transmission on detection and control of small ruminant lentivirus group C infections. Veterinary Microbiology, Amsterdam, v. 135, n. 3-4, p. 231-238, 2009.

GREGO, E.; BERTOLOTTI, L.; QUASSO, A.; PROFITI, M.; LACERENZA, D.; MUZ, D.; ROSATI, S. Genetic characterization of small ruminant Lentivirus in Italian mixed flocks: evidence for a novel genotype circulating in a local goat population. Journal of General Virology, Londres, v. 88, n. 12, p. 3423-3427, 2007.

HOSMER, D. W.; LEMESHOW, S. Applied logistic regression. New York: John Wiley and Sons, 2000. 375 p.

LIMA, C. C. V.; COSTA, J. N.; SOUZA, T. S.; MARTINEZ, P.; COSTA NETO, A. O.; ANUNCIAÇÃO, A. V. M.; ALMEIDA, M. G. A. R.; ARAÚJO, B. R.; PINHEIRO, R. R. Inquérito soroepidemiológico do lentivírus caprino e perfil das criações de caprinos na região do Baixo Médio São Francisco (BA). Arquivos do Instituto Biológico, São Paulo, v. 80, n. 3, p. 288-296, 2013.

MAIA, D. S. A. A feira de gado na cidade: encontros, conversas e negócios. Revista Formação, Presidente Prudente, v. 1, n. 14, p. 12-30, 2007.

MARTINEZ, P. M.; COSTA, J. N.; SOUZA, T. S.; ANUNCIAÇÃO, A. V. M.; PINHEIRO, R. R. Anticorpos contra o vírus da Maedi-Visna em rebanhos ovinos da microrregião de Juazeiro - Bahia. Ciência Animal Brasileira, Goiânia, v. 10, n. 3, p. 603-608, 2009.

MELO, E. X.; ALMEIDA, E. C.; MENDONÇA, K. M. N.; NASCIMENTO, S. A.; SILVA, J. C. R.; MARVULO, M. F. V.; RIZZO, H.; CASTRO, R. S. Soroprevalência da infecção por lentivírus de pequenos ruminantes em abatedouros do estado de Pernambuco, Brasil. Arquivos do Instituto Biológico, São Paulo, v. 83, n. e0462015, p. 1-4, 2016.

MENDONÇA, C. E. D.; BARROS, S. L. B.; MENDONÇA, M. A. D.; GUIMARÃES, V. A. A.; PINHEIRO, R. R. Ocorrência de anticorpos contra o vírus Maedi-Visna em ovinos Santa Inês, no estado de Sergipe, Brasil. Arquivos do Instituto Biológico, São Paulo, v. 80, n. 3, p. 346-351, 2013.

MOURA SOBRINHO, P. A. M.; RAMOS, T. R. R.; FERNANDES, C. H. C.; CAMPOS, A. C.; COSTA, L. M.; CASTRO, R. S. Prevalência e fatores associados à infecção por Lentivírus de pequenos ruminantes em caprinos no estado do Tocantins. Ciência Animal Brasileira, Goiânia, v. 11, n. 1, p. 117-124, 2010.

NOGUEIRA FILHO, A.; FIGUEIREDO JÚNIOR, C. A.; YAMAMOTO, A. Mercado de carne, leite e pele de caprinos e ovinos no Nordeste. Fortaleza: Banco do Nordeste do Brasil, 2010. 128 p. 
NUNES, A. M. B. (Re) pecuarização e família no semiárido nordestino: um estudo sobre diferenciação social entre agricultores familiares no Sertão do Pajeú (PE). Revista Brasileira de História \& Ciências Sociais, São Leopoldo, v. 5, n. 9, p. 88-104, 2013.

OLIVEIRA, M. M. M.; CASTRO, R. S.; CARNEIRO, K. L.; NASCIMENTO, S. A.; CALLADO, A. K. C.; ALENCAR, C. S. A.; COSTA, L. S. P. Anticorpos contra Lentivírus de Pequenos Ruminantes em caprinos e ovinos em abatedouros do estado de Pernambuco. Arquivo Brasileiro de Medicina Veterinária e Zootecnia, Belo Horizonte, v. 58, n. 5, p. 945-949, 2006.

OLIVEIRA, M. M. M.; MELO, M. A.; ANDRADE, P. P.; GOMES, S. M.; CAMPOS, A. C.; NASCIMENTO, S. A.; CASTRO, R. S. Western blot para o diagnóstico das infecções pelos Lentivírus de Pequenos Ruminantes em caprinos: um método simples para a produção de antígeno. Arquivo do Instituto Biológico, São Paulo, v. 75 , n. 3, p. 263-270, 2008.

PETERHANS, E.; GREENLAND, T.; BADIOLA, J.; HARKISS, G.; BERTONI, G.; AMORENA, B.; LIASZEWICZ, M.; JUSTE, R.; KRABNIG, R.; LAFONT, J.; LENIHAN, P.; PÉTURSSON, G.; PRITCHARD, G.; THORLEY, J.; VITU, C.; MORNEX, J.; PÉPIN, M. Routes of transmission and consequences of small ruminant Lentiviruses (SRLVs) infection and eradication schemes. Veterinary Research, Londres, v. 35, n. 3, p. 257-274, 2004.

PINHEIRO, R. R. Virus de artrite encefalite caprina: desenvolvimento padronização de ensaios imunoenzimáticos (Elisa e Dot-Blot) e estudo epidemiológico no Estado do Ceará. 2001. Tese (Doutorado em Ciência Animal) - Escola de Veterinária, Universidade Federal de Minas Gerais, Belo Horizonte.

PINHEIRO, R. R.; BRITO, R. L. L.; RODRIGUES, A. S.; DIAS, R. P.; ANDRIOLI, A.; GOUVEIA, A. M. G. Protocolo de Immunoblotting para diagnóstico da artrite-encefalite caprina. Sobral: Embrapa Caprinos e Ovinos, 2011. 4 p. (Embrapa Caprinos e Ovinos. Comunicado técnico, 122). Disponível em: $<$ http://ainfo. cnptia.embrapa.br/digital/bitstream/item/43727/1/UMTCOT-122.pdf>. Acesso: 14 set. 2015.

PINHEIRO, R. R.; GOUVEIA, A. M. G.; ALVES, F. S. F. Prevalência da infecção pelo vírus da artrite-encefalite caprina no Estado do Ceará, Brasil. Ciência Rural, Santa Maria, v. 31, n. 3, p. 449-454, 2001.

PINHEIRO, R. R.; GOUVEIA, A. M. G.; ALVES, F. S. F.; HADDAD, J. P. A. Aspectos epidemiológicos da caprinocultura cearense. Arquivo Brasileiro de Medicina Veterinária e Zootecnia, Belo Horizonte, v. 52, n. 5, p. 534-543, 2000.
PINHEIRO, R. R.; PINHEIRO, A. A.; SIDER, L. H.; FERNANDES, L. B. S.; OLIVEIRA, E. L.; SOUSA, A. L. M.; ALVES, F. S. F.; CRUZ, J. C. M. Lentiviroses de pequenos ruminantes: principais métodos de diagnóstico. Sobral: Embrapa Caprinos e Ovinos, 2012. 42 p.

PISONI, G.; QUASSO, A.; MORONI, P. Phylogenetic analysis of small-ruminant Lentiviruses subtype B1 in mixed flocks: evidence for natural transmission from goats to sheep. Virology, Nova Yorque, v. 339, n. 2, p. 147-152, 2005.

RIET-CORREA, B.; SIMÕES, S. V. D.; RIET-CORREA, F. Sistemas produtivos de caprinocultura leiteira no semiárido nordestino: controle integrado das parasitoses gastrointestinais visando contornar a resistência antihelmíntica. Pesquisa Veterinária Brasileira, Seropédica, v. 33, n. 7, p. 901-908, 2013.

SANTIAGO, L. B.; ALVES, F. S. F.; PINHEIRO, R. R. Lentiviroses de pequenos ruminantes e brucelose ovina no Brasil. Sobral: Embrapa Caprinos e Ovinos, 2012. 11 p. (Embrapa Caprinos e Ovinos. Nota técnica, 1). Disponível em: <http://www.alice.cnptia.embrapa.br/ handle/doc/950115>. Acesso em: 4 nov. 2015.

SARDI, S. I.; SENA, G. S. R.; CAMPOS, G. S.; SANTOS, G. R.; MAIA NETO, A. L.; AVILA, L. N. Ocorrência de lentivírus de pequenos ruminantes no semiárido baiano e perfil da caprino/ovinocultura na região. Ciência Animal Brasileira, Goiânia, v. 13, n. 4, p. 494-503, 2012.

SILVA, J. S.; CASTRO, R. S.; MELO, C. B.; FEIJÓ, F. M. C. Infecção pelo vírus da artrite encefalite caprina no Rio Grande do Norte. Arquivo Brasileiro de Medicina Veterinária e Zootecnia, Belo Horizonte, v. 57, n. 6, p. 726-731, 2005.

SILVA, M. L. C. R.; CASTRO, R. S.; MAIA, R. C.; NASCIMENTO, S. A.; GOMES, A. L. V.; AZEVEDO, S. S. Lentivírus em caprinos leiteiros do semiárido paraibano: prevalência, fatores de risco e detecção molecular. Pesquisa Veterinária Brasileira, Seropédica, v. 33, n. 4, p. 453-458, 2013.

SILVA, M. M.; FARIA JÚNIOR, S. P.; MARTINS, M. F.; RABELLO, P.; PASCOAL, P. M.; BERTAGNON, H. G.; SCHEIBEL, M.; GARCIA, M. Efeito da verminose na resposta imune em caprinos. Semina: Ciências Agrárias, Londrina, v. 23, n. 1, p. 15-19, 2002.

SOUSA, W. H. O agronegócio da caprinocultura de corte no Brasil. Tecnologia \& Ciência Agropecuária, João Pessoa, v. 1, n. 1, p. 51-58, 2007.

SOUZA, T. S.; PINHEIRO, R. R.; COSTA, J. N.; LIMA, C. C. V.; ANDRIOLI, A.; AZEVEDO, D. A. A.; SANTOS, V. W. S.; ARAÚJO, J. F.; SOUSA, A. L. M.; PINHEIRO, D. N. S.; FERNANDES, F. M. C.; COSTA NETO, A. O. 
Interspecific transmission of small ruminant Lentiviruses from goats to sheep. Brazilian Journal of Microbiology, São Paulo, v. 46, n. 3, p. 867-874, 2015.

TEIXEIRA, W. C.; AZEVEDO, E. O.; NASCIMENTO, S. A.; MAVULO, M. F. V.; RIZZO, H.; SILVA, J. C. R.; CASTRO, R. S. Soroprevalência de Maedi-visna em rebanhos ovinos do estado do Maranhão, Brasil. Revista Brasileira de Ciência Veterinária, Niterói, v. 23, n. 1-2, p. 42-47, 2016 b.

TEIXEIRA, W. C.; SANTOS, H. P.; VESCHI, J. L. A.; NASCIMENTO, S. A.; SILVA, J. C. R.; MAVULO, M. F. V.; RIZZO, H.; CASTRO, R. S. Prevalência da infecção pelo Vírus da Artrite Encefalite Caprina em rebanhos caprinos do estado do Maranhão, Brasil. Revista Brasileira de Medicina Veterinária, Rio de Janeiro, v. 38, n. 1, p. 1-6, 2016a.

THRUSFIELD, M. Veterinary epidemiology. $3^{\text {th }}$ ed. Oxford: Blackwell Science, 2007. 624 p.
VILLORIA, M.; LEGINAGOIKOA, I.; LUJÁN, L.; PÉREZ, M.; SALAZAR, E.; BERRIATUA, E.; JUSTE, R. A.; MINGUIJÓN, E. Detection of small ruminant Lentivirus in environmental samples of air and water. Small Ruminant Research, Amsterdam, v. 110, n. 2-3, p. 155-160, 2013.

WORLD ORGANIZATION FOR ANIMAL HEALTH OIE. Arttritis/encefalitis caprina y Maedi-Visna. Manual de la OIE sobre animales terrestres. Paris: OIE, 2008. Available at: <http://web.oie.int/esp/normes/ mmanual/ pdf_es_2008/2.07.03-04.\%20Artritis-Encefalitis $\% 20$ caprina $\% 20 y \% 20$ Maedi $\% 20$ Visna. pdf $>$. Accessed at: 10 nov. 2015.

ZAR, J. H. Biostatistical analysis. $4^{\text {th }}$ ed. Upper Saddle River: Prentice Hall, 1999. 663 p. 